OPEN ACCESS

Edited by:

Yue Xiao,

Wuhan University of Technology,

China

Reviewed by:

Dongliang Kuang,

Chang'an University, China

Goshtasp Cheraghian,

Technische Universitat Braunschweig,

Germany

*Correspondence:

Siong Kang Lim

sklim@utar.edu.my

Yee Ling Lee

yllee@utar.edu.my

Ming Kun Yew

yewmk@utar.edu.my

Specialty section: This article was submitted to

Construction Materials,

a section of the journal Frontiers in Built Environment

Received: 15 December 2021

Accepted: 14 January 2022

Published: 28 February 2022

Citation:

Lim SK, Lee YL, Yew MK, Ng WW, Lee FW, Kwong KZ and Lim JH (2022) Mechanical Properties of Lightweight Foamed Concrete With Ceramic Tile

Wastes as Partial Cement

Replacement Material.

Front. Built Environ. 8:836362.

doi: 10.3389/fbuil.2022.836362

\section{Mechanical Properties of Lightweight Foamed Concrete With Ceramic Tile Wastes as Partial Cement Replacement Material}

\author{
Siong Kang Lim *, Yee Ling Lee *, Ming Kun Yew*, Wen Wei Ng, Foo Wei Lee, Kok Zee Kwong \\ and Jee Hock Lim
}

Department of Civil Engineering, Lee Kong Chian Faculty of Engineering and Science, Universiti Tunku Abdul Rahman, Bandar Sungai Long, Malaysia

The production of concrete emits greenhouse gases which aggravate global warming. Meanwhile, ceramic tile wastes generated from manufacturing factories, construction sites, and building demolition projects disposed of by landfills create land and water pollution. Therefore, in this study, the suitability of ceramic tile wastes (CTW) in powder form to partially replace cement in lightweight foamed concrete was investigated with the aim to discover a greener construction material. Once the research outputs show that the ceramic tile dust can appropriately serve as a replacement, environmental impact on air, land, and water pollution can all be reduced. Three types of lightweight foamed concrete with $0 \%, 25 \%$, and $50 \%$ ceramic tile wastes as partial cement replacement material were prepared with a target density of $1,200 \mathrm{~kg} / \mathrm{m}^{3}$, namely, LFC-CTWO, LFC-CTW25, and LFC-CTW50, respectively. The effects of ceramic tile wastes on the engineering properties of lightweight foamed concrete were investigated. Concrete specimens were water-cured and tested for various mechanical properties at the concrete ages of 7,28 , and 56 days. Results from the lab experiments showed that the incorporation of $25 \%$ ceramic tile wastes into lightweight foamed concrete was more feasible than that of 50\%. LFC-CTW25, which performed better than LFC-CTWO for the splitting tensile strength test at day 56 . The results for the compressive strength test, modulus of elasticity, and compressive toughness test showed a minor reduction after the incorporation of ceramic tile wastes. Based on the results, it can be concluded that it is feasible to use ceramic tile wastes up to $25 \%$ as partial cement replacement material to produce foamed concrete.

Keywords: ceramic tile wastes, engineering properties, lightweight, foamed concrete, partial cement replacement material

\section{INTRODUCTION}

Foamed concrete is a cellular concrete class under lightweight concrete because it is a low-density concrete. Foamed concrete is a cementitious material formed by mechanically entraining foams into plastic mortar during the mixing stage with a minimum volume of $20 \%$. Foamed concrete has the characteristics related to its fluidity, low self-weight, and excellent thermal and sound insulation properties (Zhao et al., 2015). For foamed concrete, foam volume added into plastic mortar is usually around $40 \%-80 \%$ out of the total volume, and the bubbles' diameter typically varies from 0.1 to 
$0.15 \mathrm{~mm}$. In terms of 28 days, compressive strength and dry density of foamed concrete range from 1 to $10 \mathrm{~N} / \mathrm{mm}^{2}$ and 400 to $1,600 \mathrm{~kg} / \mathrm{m}^{3}$ respectively, where the compressive strength has increased exponentially in relation with the dry density. However, the results of strength and density vary with the mixed composition of base materials (Brady et al., 2001).

To produce foamed concrete, cement, sand, water, and preformed foam are the base mix materials. The low-density property of this foamed concrete increased its popularity in the construction field as it helps in reducing the self-weight and size of structures, reducing cement usage, and thus reducing overall construction material cost (Brady et al., 2001). Besides, this type of concrete is also known for its free-flowing but cohesive properties. It gives advantages in placing and finishing stages as foamed concrete does not need compaction and can easily be pumped to its desired destination to perform work like filling up small holes or flattening irregular surfaces. Other than that, foamed concrete's texture surface accompanied by its microstructural elements improved some properties of concrete, for example, thermal insulation, sound absorption, and fire insulation (Amran et al., 2015).

This project is conducted as an effort to solve the problems arising in the construction sector with producing a new innovative, environmentally friendly, and greener concrete to solve the sustainability issue of construction materials. The main environmental problem generated from the production of cement is the heat generated (Tiong et al., 2020); and mining activities heavily deplete natural materials every year, while the emission of carbon dioxide into the atmosphere increases carbon footprint. As for information, cement production itself is contributing $5 \%$ to the annual anthropogenic global carbon dioxide production, and the rapidly developing country of China alone is contributing 3\% (Crow 2008). Besides that, the ceramic tile industry also has created environmental issues such as the ceramic tile wastes generated from manufacturing factories, construction sites, and building demolition projects, disposed of by the practice of landfilling that creates land and water pollution (Shah 2015). Ceramic products are important construction materials used in buildings. Ceramic is a mixture of clay, sand, and other natural materials, molded into the desired shape, and then fired at a high-temperature kiln (Bhavana and Rambabu 2017). Ceramic wastes like ceramic floor tiles, ceramic wall tiles, brick wall debris, and ceramic utensils are major waste contributors in construction and demolition activity, which account for about $54 \%$ of waste (Daniyal and Ahmad 2015). A high quantity of manufactured tiles, at 1.5 million tonnes of ceramic waste trashed out by manufacturers each year, is expected (Javier et al., 2016). Also, a report had examined that out of the total ceramic materials being transported to the site, only $70 \%$ of the ceramic materials will be correctly used in the planned position; the remainder will turn into wastes due to the poor skills and inappropriate handling of the materials by laborers (Jacob et al., 2017). Because both types of construction materials have a great negative impact on the environment, in the near future, it is projected that their combination, ceramic waste and cement, might reduce their negative impact to the environment, especially by reducing the carbon footprint.

Ceramic tile is a lightweight material that weighs about $14 \mathrm{~kg} /$ $\mathrm{m}^{2}$, as it is made under a high heating temperatures. Therefore, it has good fire resistance and at the same time has a high fracture strength of up to $39 \mathrm{MPa}$. Besides, this material is good and convenient to use as a building material because of its strain-free property and because it does not require extra polishing work. In addition, ceramic tile is also a good protective material for building structures as it is low in water absorption and can resist both acid and alkali toxic agents. Lastly, the thermal insulating properties from ceramic tile helps to provide an even temperature for a given space and fewer temperature changes and thus promotes energy saving (Bhavana and Rambabu 2017).

In the past few years, ceramic tiles had been investigated experimentally by researchers to study their effects on concrete. The results on engineering properties in terms of workability, compressive strength, splitting tensile strength, and modulus of elasticity of partially replaced concrete are reviewed as follows. In terms of workability, ceramic tile reduced the slump value. The reduction of workability was predicted to be caused by the high water absorption ability of tiles (Bhavana and Rambabu 2017; Daniyal and Ahmad 2015). Bhogilal and Jayantilal (2018) studied the selfcompacting concrete (SCC) combined with ceramic waste powder from tiles as partial replacement for cement with replacement levels of $0 \%, 10 \%$, and $20 \%$. The author found out that the slump value and compressive strength decreased with an increase of ceramic waste powder. Apart from that, ceramic waste powder was also used to prepare SCC and conventional concrete by El-Dieb et al. (2018). In their study, cement was slightly substituted by ceramic waste powder at varying levels of $0 \%, 10 \%, 20 \%, 30 \%$, and $40 \%$ of the cement weight. Results were computed and discussed for the concrete with Grades M25 and M50. A significant reduction in the slump value as well as compressive strength of SCC with increment in the quantity of ceramic waste powder was found. For ordinary Portland cement (OPC) replacement proportion in paver blocks, compressive strength was found to be optimum at $30 \%$ (Aswin et al., 2018). For coarse aggregate replacement proportion, compressive strength was found to be optimum at 25\% (Mohan et al., 2018; Adekunle et al., 2017). Mohan et al. (2018) recommended that $25 \%$ clay tile chip replacement for coarse aggregate is the best proportion since the reduction in strength is the smallest compared to other proportions, which had an around 9\% drop in value. Also, the modulus of elasticity has an inverse relation with the weight percentage of the clay tile chips added. By comparing the result of the full replacement specimen with the nonreplacement specimen, a drop of modulus elasticity was found with a value of 58\% (Mohan et al., 2018). For fine aggregate replacement proportion, compressive strength was found to be optimum at $5 \%$ (Adekunle et al., 2017). From the above literature, it is found that studies for ceramic waste powder as partial cement replacement material in lightweight foamed concrete are still lacking and limited.

Therefore, to make a more environmentally friendly concrete which reduces carbon footprint, as well as to fill the research gap on partial replacement of Portland cement in lightweight foamed concrete as an approach in the current trend, through this project, we investigated the suitability of ceramic tile wastes to partially replace cement in the lightweight foamed concrete, which is extremely important. Once the research outputs show that ceramic tile dust can appropriate serve as a replacement, the 


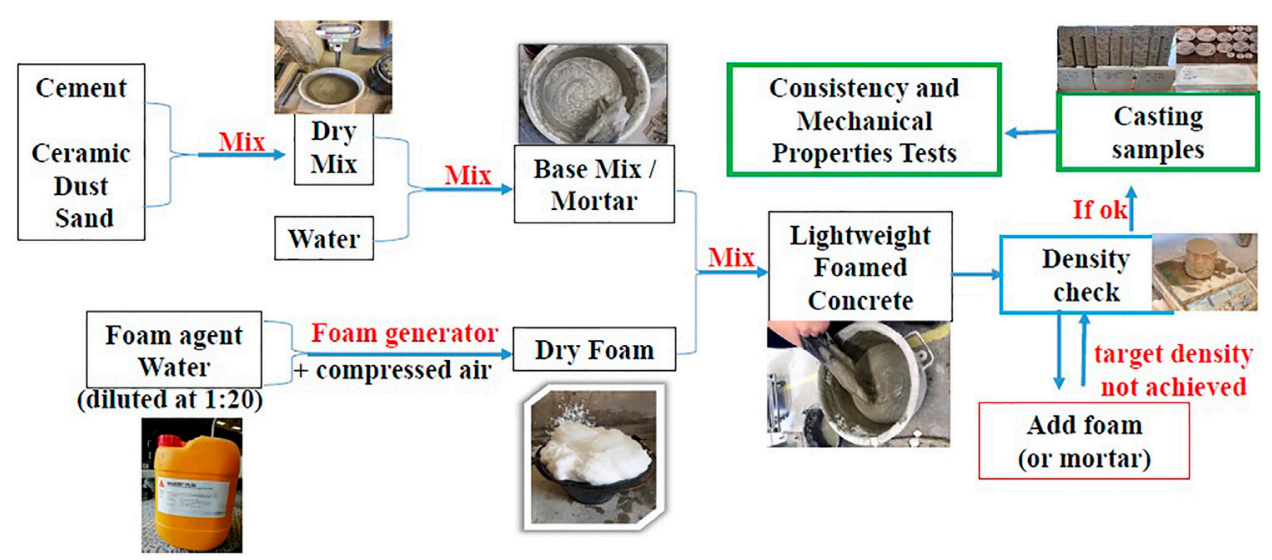

FIGURE 1 | Graphical abstract of this study.

TABLE 1 | Chemical composition analysis by weight percentage of the localized OPC and ceramic tile wastes used (Lim et al., 2013; Global Bio Synergy Sdn. Bhd N.D.).

\begin{tabular}{lcc} 
Chemical content & \multicolumn{2}{c}{ Weight, \% } \\
\cline { 2 - 3 } & OPC & Ceramic tile wastes powder \\
\hline Calcium Oxide, $\mathrm{CaO}$ & 65.00 & 46.9 \\
Silicon Dioxide, $\mathrm{SiO}_{2}$ & 20.10 & 29.5 \\
Aluminium Oxide, $\mathrm{Al}_{2} \mathrm{O}_{3}$ & 4.90 & 13.0 \\
Iron (III) Oxide, $\mathrm{Fe}_{2} \mathrm{O}_{3}$ & 2.50 & 3.5 \\
Zinc as $\mathrm{ZnO}$ & - & 2.0 \\
Loss of Ignition, $\mathrm{LOI}$ & 2.40 & 2.3 \\
\hline
\end{tabular}

environmental impact of air, land, and water pollution can all be reduced. Thus, a greener construction material of lightweight foamed concrete will be discovered, which could be the novelty of this study.

Overall, this study is carried out to investigate engineering properties in terms of density, consistency, stability, compressive and splitting tensile strengths, modulus of elasticity, and compressive toughness of the lightweight foamed concrete with ceramic tile powder as partial cement replacement material. In the entire study, lightweight foamed concrete with $0 \%, 25 \%$, and $50 \%$ ceramic tile powder as partial cement replacement material were developed, where the $0 \%$ replacement ceramic tile powder serves as a reference mix (LFC-CTW0). The targeted density for these three types of foamed concrete is $1,200 \mathrm{~kg} / \mathrm{m}^{3}$ with a tolerance of $\pm 50 \mathrm{~kg} / \mathrm{m}^{3}$. The graphical abstract for the study is shown in Figure 1, showing the schematic flow of the work scope.

\section{EXPERIMENTAL DETAILS}

\section{Raw Material Preparation}

Basic materials used to develop lightweight foamed concrete with ceramic tile wastes as partial cement replacement were OPC, preformed foam, water, sand, and ceramic tile wastes. Local OPC was employed. This type of cement falls under Type I Portland cement with a strength class of 42.5 , which is in accordance with ASTM C150 (ASTM 2005a) and is a product certified under MS EN 197-1 (Standards Malaysia 2014). The chemical composition analysis by weight percentage is shown in Table 1 . The BET surface area obtained was $1.1851 \mathrm{~m}^{2} / \mathrm{g}$. The cement was sieved through a $300 \mu \mathrm{m}$ sieve opening according to ASTM C136 (ASTM 2006a) to remove partially hydrated cement particles. The sieved cement was then stored in an airtight container to isolate it from the moisture in the atmosphere.

The foaming agent applied in this study is Sika-AER, which complies with ASTM C260 (ASTM 2016). The density of the foaming agent is $1.01 \mathrm{~kg} / \mathrm{L}$; it is a colorless liquid containing chemicals of synthetic surface-active agents and polymer. The ratio of synthetic air-entraining agent to water measured by volume is 1:20 (Sika 2017). The preformed foam was made by adding water with a foaming agent into a foam generator. The foam generator created foams by homogenously mixing up water and the foaming agent. Upon pumping out the liquid mixture, compressed air with a pressure of $0.5 \mathrm{MPa}$ was applied to it to solidify the liquid into foam bubbles with a density of $45 \pm 5 \mathrm{~kg} / \mathrm{m}^{3}$.

Fine sand used in the production of lightweight foamed concrete is in accordance with ASTM C778 (ASTM 2006b). Before casting, it was oven-dried at a temperature of $105^{\circ} \mathrm{C}$ for $24 \mathrm{~h}$ to remove the moisture content of the sand particle. Then, sieving of dry sand through a $600 \mu \mathrm{m}$ sieve opening was performed according to ASTM C136 (ASTM 2006a). In this study, water adopted was sourced from municipal tap water, which contains no harmful impurities and complies with ASTM C1602 (ASTM 2006c).

Ceramic tile waste was used as a cement replacement material in this entire study, where two levels of cement replacement of $25 \%$ and $50 \%$ were studied. Ceramic tile wastes from a local supplier came in a package of powder forms that were made up by processing the by-product of ceramic tiles from the tile factory. Before concrete casting begins, ceramic tile waste powder was sieved through a $300 \mu \mathrm{m}$ sieve opening in advance to obtain fine particle size in accordance with ASTM C136 (ASTM 2006a). 


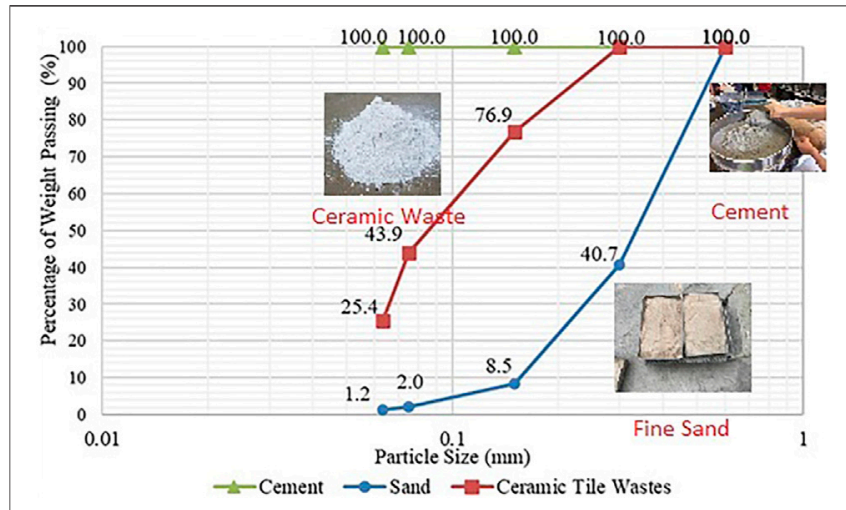

FIGURE 2 | Semi-log graph of percentage of weight passing against particle size for cement, sand, and ceramic tile wastes.

After the sieving process, it was then stored in an airtight container to isolate it from the moisture in the atmosphere. The chemical composition of ceramic tile waste was analyzed using X-ray fluorescence (XRF) (Global Bio Synergy Sdn, 2016). The chemical composition of ceramic tile wastes by weight percentage is presented in Table 1. The BET surface area is $1.6235 \mathrm{~m}^{2} / \mathrm{g}$. The sieve analysis result for both the fine sand used and ceramic dust is shown in Figure 2.

\section{Mixing Procedure}

All LFC specimens were cast according to standards from ASTM C192 (ASTM 2007a). Concrete making began by weighing the ordinary Portland cement, ceramic tile waste, sand, and water according to designated proportions using a weighing machine. All dry materials were mixed evenly in a dry mixing bowl. Then water was gradually added with continuous mixing until a homogenous cement-sand mortar was formed. The cement-sand mortar was then weighed using a $1-\mathrm{L}$ volume container to obtain the base density, and thus, the weight of preformed foam needed was calculated. The calculated volume of stable preformed foam was added and mixed with the base mix homogeneously, and the plastic foamed concrete was obtained with the density within $1,150-1,250 \mathrm{~kg} / \mathrm{m}^{3}$. The hardened concrete specimens were demolded after 1 day, and the hardened densities of each specimen were measured. Finally, the specimens were cured in a water tank until testing ages of 7 , 28 , and 56 days.

\section{Trial Mix}

The trial mix is a trial-and-error method for concrete mix design conducted by varying the water-to-cement ratio. The trials end by obtaining an optimum mix proportion where the performance of foamed concrete in terms of workability, densities, and compressive strength is optimized. The trial mix in this study was carried out by casting $100 \mathrm{~mm}$ lightweight foamed concrete cubic specimens with various water-to-cement ratios with an interval of 0.04 . The three sets of trial mix conducted ranged from 0.52 to $0.68,0.52$ to 0.64 , and 0.48 to 0.64 for LFC-CTW0, LFCCTW25, and LFC-CTW50, respectively. The density for every mix was controlled at $1,200 \pm 50 \mathrm{~kg} / \mathrm{m}^{3}$. The tests conducted in the trial mix stage were fresh density determination, inverted slump test, and cube compressive strength test for 7 and 28 days. The optimal water-to-cement ratio of the mix proportions for LFC-CTW0, LFC-CTW25, and LFC-CTW50 was determined based on the performance index (PI). Mix proportions of the trial mix are provided in Table 2.

\section{Plastic Property Testing}

First, the flow table test was carried out according to ASTM C230 (ASTM 2014) and ASTM C1437 (ASTM 2007b). This test was conducted before adding preformed foam into a cement-sand mortar to determine the consistency of the base mix. The inverted slump test for foamed concrete was carried out in accordance with ASTM C1611 (ASTM 2005b) in which the spreading diameters of foamed concrete were measured to investigate the flowability of foamed concrete. The plastic density determination was carried out according to ASTM C796 (ASTM 2012). Finally, the density, consistency, and stability of the foamed concrete were determined. Foamed concrete was known to be consistent and stable if the ratios obtained are close to unity.

\section{Mechanical Property Testing}

The compressive strength test was carried out according to standards from BS EN 12390-Part 3 (BSI 2002). In this test, the INSTRON 5582 test machine was employed to perform the test. The cylindrical specimen of $200 \mathrm{~mm}$ height and $100 \mathrm{~mm}$ diameter was placed vertically at the center of the machine platform and loaded axially at a rate of $2.5 \mathrm{kN} / \mathrm{s}$ until crushed. Besides, the PI of the concrete specimen was determined to know

TABLE 2 | Mix proportion of LFC-CTWO, LFC-CTW25, and LFC-CTW50 with various water-to-cement ratios.

\begin{tabular}{|c|c|c|c|c|c|}
\hline \multirow[t]{2}{*}{ Specimen name } & \multicolumn{5}{|c|}{ Materials of foamed concrete $\left(\mathrm{kg} / \mathrm{m}^{3}\right)$} \\
\hline & Cement & $\begin{array}{c}\text { Ceramic tile } \\
\text { wastes }\end{array}$ & Sand & Water & Foam \\
\hline $\begin{array}{l}L_{F C}{ }^{a}-C T W O^{b}- \\
0.52^{e}\end{array}$ & 476 & - & 476 & 248 & 23 \\
\hline LFC-CTWO-0.56 & 469 & - & 469 & 263 & 24 \\
\hline LFC-CTWO-0.60 & 462 & - & 462 & 277 & 25 \\
\hline LFC-CTWO-0.64 & 455 & - & 455 & 291 & 23 \\
\hline LFC-CTWO-0.68 & 448 & - & 448 & 304 & 23 \\
\hline $\begin{array}{l}\text { LFC- } \\
\text { CTW25다인.52 }\end{array}$ & 357 & 119 & 476 & 248 & 27 \\
\hline LFC-CTW25-0.56 & 352 & 117 & 469 & 263 & 28 \\
\hline LFC-CTW25-0.60 & 346 & 115 & 462 & 277 & 26 \\
\hline LFC-CTW25-0.64 & 341 & 114 & 455 & 291 & 25 \\
\hline $\begin{array}{l}\text { LFC- } \\
\text { CTW50 }-0.48\end{array}$ & 241 & 242 & 484 & 232 & 28 \\
\hline LFC-CTW50-0.52 & 238 & 238 & 476 & 248 & 28 \\
\hline LFC-CTW50-0.56 & 234 & 234 & 469 & 263 & 26 \\
\hline LFC-CTW50-0.60 & 231 & 231 & 462 & 277 & 23 \\
\hline LFC-CTW50-0.64 & 227 & 227 & 455 & 291 & 24 \\
\hline
\end{tabular}

a Lightweight foamed concrete.

${ }^{b}$ LFC with $0 \%$ ceramic tile wastes as partial cement replacement material.

${ }^{\circ}$ LFC with $25 \%$ ceramic tile wastes as partial cement replacement material.

${ }^{d}$ LFC with $50 \%$ ceramic tile wastes as partial cement replacement material.

${ }^{e}$ Water-to-cement ratio. 
TABLE 3 | Fresh state properties of LFC-CTWO, LFC-CTW25, and LFC-CTW50 with various water-to-cement ratios.

\begin{tabular}{|c|c|c|c|c|c|c|c|}
\hline Specimen name & Fresh density $\left(\mathrm{kg} / \mathrm{m}^{3}\right)$ & Hardened density $\left(\mathrm{kg} / \mathrm{m}^{3}\right)$ & Oven-dry density $\left(\mathbf{k g} / \mathrm{m}^{3}\right)$ & Flow table test (no. of drops) & Spreading diameter $(\mathrm{mm})$ & Consistency & Stability \\
\hline LFC-CTWO-0.52 & 1,190 & 1,203 & 1,063 & 12 & 505 & 0.99 & 0.99 \\
\hline LFC-CTWO-0.56 & 1,230 & 1,238 & 1,079 & 8 & 615 & 1.03 & 0.99 \\
\hline LFC-CTWO-0.60 & 1,232 & 1,219 & 1,058 & 5 & 670 & 1.03 & 1.01 \\
\hline LFC-CTWO-0.64 & 1,231 & 1,250 & 1,077 & 4 & 795 & 1.03 & 0.98 \\
\hline LFC-CTWO-0.68 & 1,226 & 1,248 & 1,054 & 2 & 850 & 1.02 & 0.98 \\
\hline LFC-CTW25-0.52 & 1,236 & 1,209 & 1,064 & 13 & 560 & 1.03 & 1.02 \\
\hline LFC-CTW25-0.56 & 1,210 & 1,222 & 1,051 & 11 & 605 & 1.01 & 0.99 \\
\hline LFC-CTW25-0.60 & 1,230 & 1,230 & 1,061 & 7 & 678 & 1.03 & 1.00 \\
\hline LFC-CTW25-0.64 & 1,210 & 1,229 & 1,025 & 5 & 753 & 1.01 & 0.98 \\
\hline LFC-CTW50-0.48 & 1,204 & 1,167 & 1,012 & 20 & 485 & 1.00 & 1.03 \\
\hline LFC-CTW50-0.52 & 1,231 & 1,261 & 1,078 & 18 & 603 & 1.03 & 0.98 \\
\hline LFC-CTW50-0.56 & 1,220 & 1,211 & 1,029 & 14 & 618 & 1.02 & 1.01 \\
\hline LFC-CTW50-0.60 & 1,219 & 1,218 & 1,027 & 11 & 668 & 1.02 & 1.00 \\
\hline LFC-CTW50-0.64 & 1,212 & 1,217 & 1,017 & 9 & 788 & 1.01 & 1.00 \\
\hline
\end{tabular}

the compressive strength per $1,000 \mathrm{~kg} / \mathrm{m}^{3}$ density. This parameter allows the comparison of the compressive strength for a variation of hardened density.

The splitting tensile test was carried out according to standards from BS EN 12390-Part 6 (BSI 2000b) and equivalent to ASTM C496 (ASTM 2004). In this test, the $100 \mathrm{kN}$ flexural test machine DHR 2000 was employed to perform the test. Firstly, a cylindrical specimen of $200 \mathrm{~mm}$ height and $100 \mathrm{~mm}$ diameter was placed horizontally on the prepared machine steel mold. Two thin plywood-bearing strips were placed each on the top and bottom of the horizontally laid cylindrical specimen. Then, it was loaded axially at a rate of $2.00 \mathrm{kN} / \mathrm{s}$; the maximum axial load value applied was recorded.

The modulus of elasticity test was carried out according to standards from ASTM C469 (ASTM 2002). The INSTRON 5582 test machine was employed to perform the test, and a cylindrical specimen of $200 \mathrm{~mm}$ height and $100 \mathrm{~mm}$ diameter was adopted. The loading rate of $2.50 \mathrm{kN} / \mathrm{s}$ was applied. The strains were marked down with a data logger for every $0.5 \mathrm{MPa}$ increase in pressure and ended with the failure of the specimen. Lastly, the compressive toughness was found from the plotted graph of compressive stress $v s$. longitudinal strain.

\section{RESULTS AND DISCUSSION}

\section{Fresh Property Analysis}

The fresh state properties of LFC-CTW0, LFC-CTW25, and LFCCTW50 with various water-to-cement ratios are tabulated in Table 3.

From Table 3, it is observed that the fresh densities of the three LFC-CTW0, LFC-CTW25, and LFC-CTW50 had laid in the desired range, which is between 1,150 and $1,250 \mathrm{~kg} / \mathrm{m}^{3}$. The flow table test was performed to measure the workability and control the consistency of the base mix. An inversely proportional relationship is found between the drop number of flow table and water-to-cement ratio when comparing among the same ceramic tile waste replacement proportions. Besides, when comparing the dropping times of the flow table with the same water-to-cement ratio but different replacement proportions, it is observed that when the ceramic tile wastes increase in volume, the number of drops increases. A similar trend of the number of drops for the flow table also can be found in the previous study from Lee et al. (2021). Besides, the results showed similar output as stated in studies by Bhavana and Rambabu (2017) and Daniyal and Ahmad (2015). The ceramic tile waste BET surface area by using nitrogen absorption at $100^{\circ} \mathrm{C}$ obtained $1.6235 \mathrm{~m}^{2} / \mathrm{g}$, which is larger than the surface area of the cement. The larger surface area of ceramic tile waste can cause high demand for water, which is also stated by Samadi et al. (2015) in his study. Therefore, it can be concluded that the decrease in water-tocement ratio, as well as the increase in ceramic tile wastes, decreases the workability of the base mix.

The inverted slump test was performed after the fresh foamed concrete was produced, with the purpose of measuring the mixture consisting of the fresh foamed concrete. The results of the inverted slump test showed a directly proportional relationship between the water-to-cement ratio and slump spreading diameters. This means that when the amount of water added into the foamed concrete increases, the workability of the foamed concrete will increase. Based on Table 3, the largest spreading diameter was achieved by LFCCTW0-0.68, which was $850 \mathrm{~mm}$; meanwhile, the smallest inverted slump diameter was achieved by LFC-CTW50-0.48, which was $485 \mathrm{~mm}$. Therefore, it can be concluded that LFCCTW0-0.68 is the most slurry foamed concrete while LFCCTW50-0.48 is the stiffest foamed concrete. However, neither the most slurry nor the stiffest foamed concrete is a desirable mix for foamed concrete. This is because an overly slurry foamed concrete is unable to hold the foam bubbles in place, which leads to segregation between bubbles and concrete mixture, while an overly stiff foamed concrete will cause the bursting of foam bubbles (Sallal 2018); both conditions will severely affect the strength performance of foamed concrete.

In addition, the workability of foamed concrete shows a slight decrement consequent of the increment of ceramic tile waste replacement in foamed concrete. The great possession of aluminum and silica, as shown in Table $\mathbf{1}$ as well as flow table drop numbers presented in Table 3, gave clues to the presence of clay cohesive property in ceramic tile wastes. Therefore, it is predicted that the cohesiveness of ceramic tile wastes increased the demand for water to work the foamed concrete. 


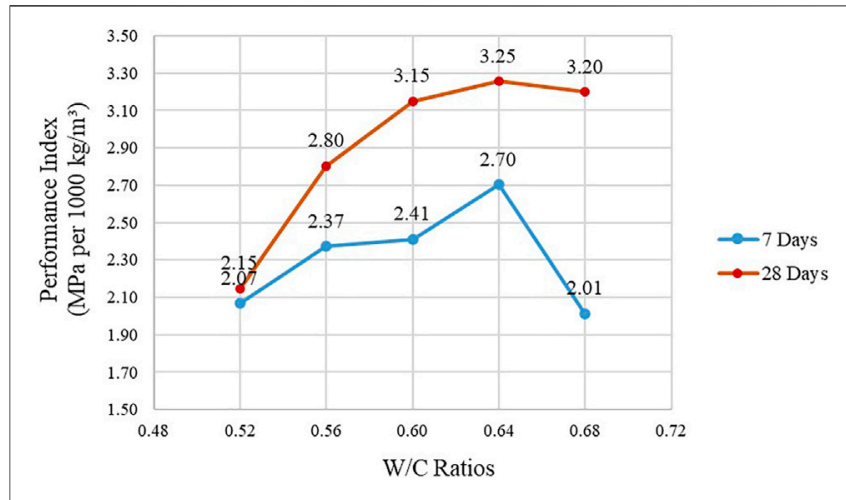

FIGURE 3 | Performance index of LFC-CTWO.

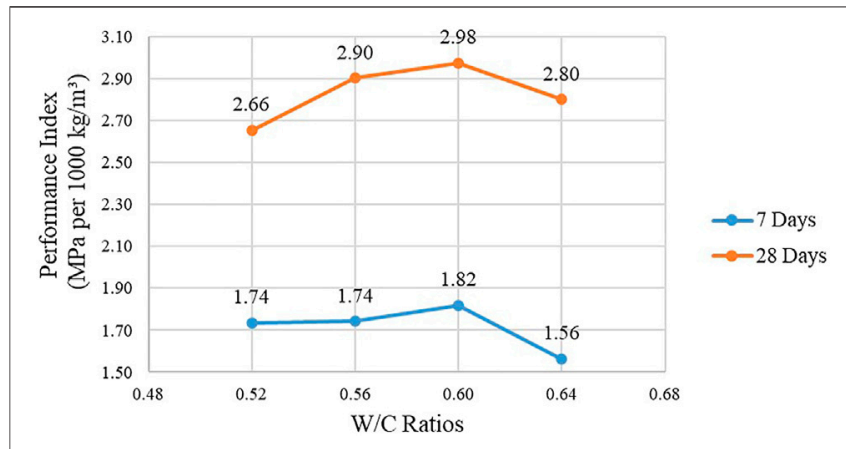

FIGURE 4 | Performance index of LFC-CTW25.

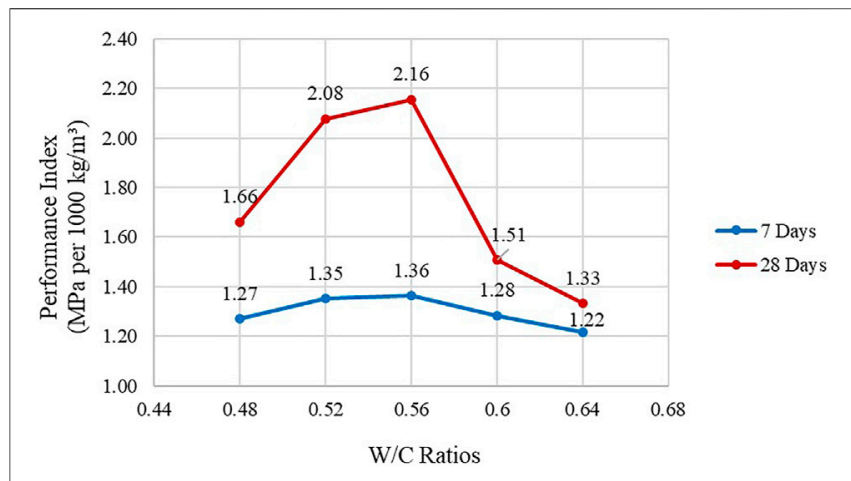

FIGURE 5 | Performance index of LFC-CTW50.

As for density consistency and stability, the three mixtures were valued nearly to unity owing to varying the water contents and foam volume. Because of that, foamed concrete produced can be ensured to have uniformly mixed and stably stand firm foam bubbles.

\section{The PI for Selection of Optimal Mix}

The 7 and 28 days' PIs for LFC-CTW0, LFC-CTW25, and LFCCTW50 are presented in Figures 3-5, respectively. The performance index serves the purpose of screening the results of the trial mix to select the optimal water-to-cement ratio mix proportion (Lim et al., 2013). The PI is used in the comparison of the strength performance of lightweight foamed concrete with and without ceramic tile wastes. This is because of the hardened densities of LFCs at the same density category that vary in the 5\% range caused by the bursting of bubbles during mixing, pouring, and casting as well as different specific gravity (SG) between cement and ceramic dust. Based on this reason, it is good to compare the strength performance of the same-category LFCs per unit density, which is in the unit $\mathrm{MPa} / 1,000 \mathrm{~kg} / \mathrm{m}^{3}$ to reflect the exact effect of ceramic tile wastes on LFCs at the same platform.

From Figures $\mathbf{3 - 5}$, it is noted that the PI is directly proportional to the age of curing. For LFC-CTW0, the highest 7 and 28 days PIs were achieved by 0.64 water-to-cement ratio mix proportion, which were 2.70 and $3.26 \mathrm{MPa}$ per $1,000 \mathrm{~kg} / \mathrm{m}^{3}$ respectively. For LFC-CTW25, the highest 7 and 28 days' PIs were achieved by the 0.60 water-to-cement ratio mix proportion, which were 1.82 and $2.98 \mathrm{MPa}$ per $1,000 \mathrm{~kg} / \mathrm{m}^{3}$, respectively. For LFC-CTW50, the highest 7 and 28 days' PIs were achieved by the 0.56 water-to-cement ratio mix proportion, which were 1.36 and $2.16 \mathrm{MPa}$ per $1,000 \mathrm{~kg} / \mathrm{m}^{3}$, respectively. Figures 3-5 depict the increase in compressive strength with the curing age. Besides, the PI results show that the strength values increase to reach the optimal w/c for the respective mix and then decrease across the increasing water content. This proves that proper consistency of foamed concrete is needed to achieve the optimal quality. In addition, when the percentage of ceramic tile waste replacement increased, the optimum $\mathrm{w} / \mathrm{c}$ obtained is reduced.

\section{Compressive Strength Performance Analysis}

The 7, 28, and 56 days' compressive strength test results for the optimal LFC-CTW0, LFC-CTW25, and LFC-CTW50 are presented in Figure 6.

From Figure 6, it is found that all three LFC-CTW0, LFCCTW25, and LFC-CTW50 increased gradually in compressive strength throughout the 56 days. LFC-CTW50 gains the lowest compressive strength at the three curing ages, yet LFC-CTW0 gains the highest compressive strength at the same curing ages. The compressive strengths of LFC-CTW25 and LFC-CTW50 were lower than that of the control specimen, which might be due to the dilution of $\mathrm{C}_{3} \mathrm{~S}$ and $\mathrm{C}_{2} \mathrm{~S}$ by the content of the ceramic tile powder, and the dilution was the dominant effect of pozzolanic reaction between the calcium hydroxide of cement and reactive silica in ceramic tile powder. Table 1 shows that ceramic tile wastes used in this project are mainly composited with $46.9 \%$ of calcium, $\mathrm{CaO}$, and $29.5 \%$ of silica, $\mathrm{SiO}_{2}$. This explains the reason for the lower early strength results for both LFC-CTW25 and LFC-CTW50 as a pozzolanic reaction is at the later ages and timeconsuming. The pozzolanic reaction happens when silica in ceramic tile wastes reacts with calcium hydroxide, $\mathrm{Ca}(\mathrm{OH})_{2}$, and strength is gained with the formation of calcium silicate hydrate, $\mathrm{CSH}$.

Besides, when comparing the compressive strength results between $25 \%$ and $50 \%$ ceramic tile waste replacement 


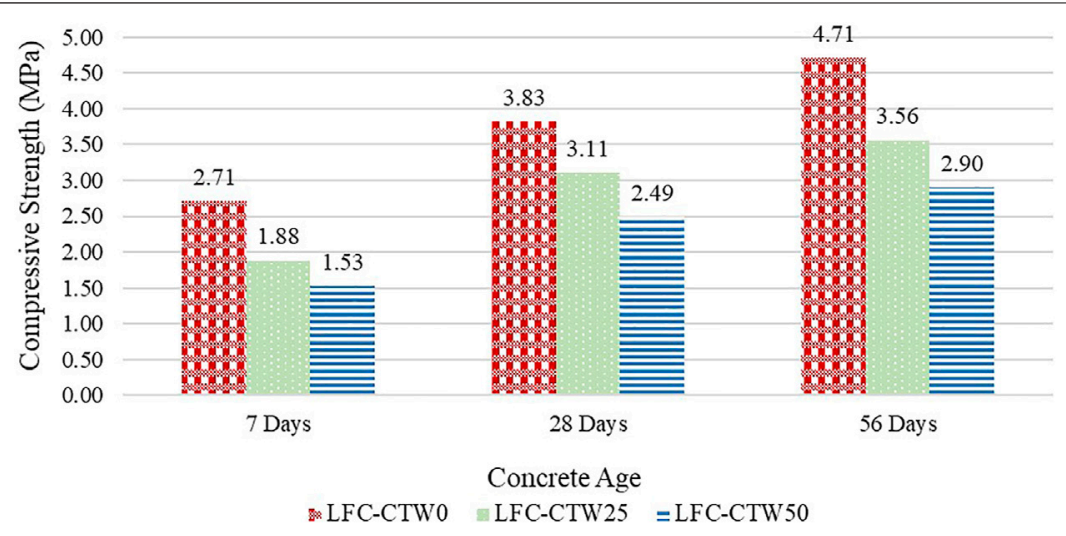

FIGURE 6 | Compressive strength of LFC-CTWO, LFC-CTW25, and LFC-CTW50 at ages of 7, 28, and 56 days.

TABLE 4 | Effect of incorporation of ceramic tile wastes in lightweight foamed concrete on its compressive strength at various concrete ages.

\begin{tabular}{llc} 
Concrete age (days) & Specimen name & Percentage of compressive strength development corresponding to LFC-CTW0 (\%) \\
\hline 7 & LFC-CTW0 & 100 \\
& LFC-CTW25 & 69 \\
& LFC-CTW50 & 56 \\
\hline 28 & LFC-CTW0 & 100 \\
& LFC-CTW25 & 81 \\
& LFC-CTW50 & 65 \\
\hline 56 & LFC-CTW0 & 100 \\
& LFC-CTW25 & 76 \\
\end{tabular}

TABLE 5 | Standard deviation of the compressive strength performance index for each mixture.

\begin{tabular}{lll} 
Concrete age (days) & Specimen name & Standard deviation based on the compressive strength performance index (MPa/1,000 $\mathbf{~ g ~} / \mathbf{m}^{\mathbf{3}}$ ) \\
\hline 7 & LFC-CTW0 & 0.410 \\
& LFC-CTW25 & 0.355 \\
& LFC-CTW50 & 0.252 \\
\hline 28 & LFC-CTW0 & 0.137 \\
& LFC-CTW25 & 0.379 \\
& LFC-CTW50 & 0.185 \\
\hline 56 & LFC-CTW0 & 0.550 \\
& LFC-CTW25 & 0.361 \\
& LFC-CTW50 & 0.331
\end{tabular}

proportions, it is observed that LFC-CTW25 tends to have better strength development. Table 4 supports the statement by showing that LFC-CTW25 obtained a higher percentage of compressive strength compared to the control's result after the early age of the first 7 days. A similar trend of the results is shown by Heidari and Tavakoli (2013), where there is slightly reduced compressive strength and water absorption capacity of the concrete with ground ceramic powder compared to the control mix. Besides, Aswin et al. (2018) also stated that for OPC replacement proportion in normal weight concrete, compressive strength was found to be optimum at $30 \%$ to gain a positive result. Table 5 shows the standard deviation for the compressive strength PI of each mixture. It can be deduced that the standard deviation is in the range of $0.137-0.550 \mathrm{MPa}$ per $1,000 \mathrm{~kg} / \mathrm{m}^{3}$. The low standard deviation indicates that the compressive strength tends to be close to the mean of the set data in each mixture.

\section{Splitting Tensile Strength Performance Analysis}

The 7, 28, and 56 days' splitting tensile strength test results for LFCCTW0, LFC-CTW25, and LFC-CTW50 are presented in Figure 7.

Split tensile strength is the resistance of the cylinder from splits and cracks under compression and indirect tension. The strength 


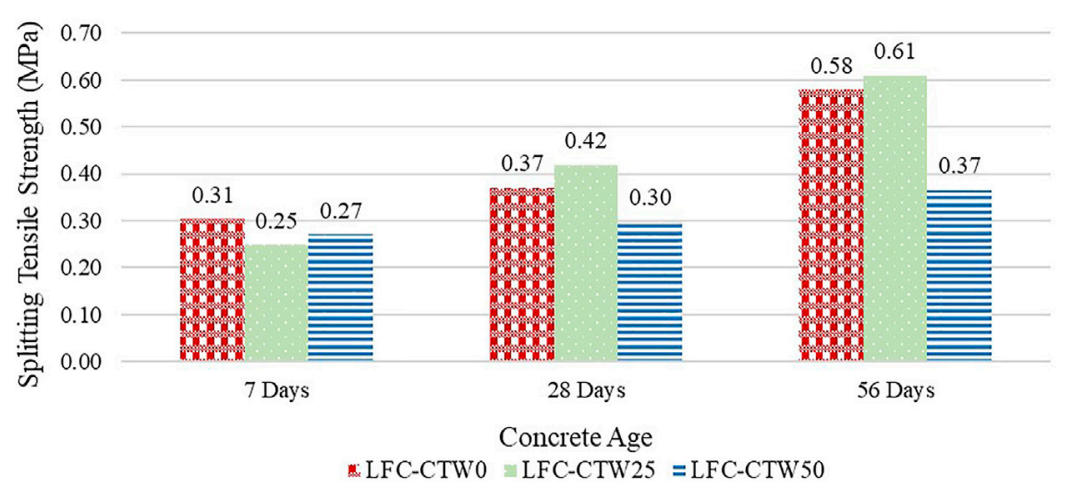

FIGURE 7 | Splitting tensile strength of LFC-CTWO, LFC-CTW25, and LFC-CTW50 at ages of 7, 28, and 56 days.

TABLE 6 | Effect of incorporation of ceramic tile wastes in lightweight foamed concrete on its splitting tensile strength at various concrete ages.

\begin{tabular}{llc} 
Concrete age (days) & Specimen name & $\begin{array}{c}\text { Percentage of tensile } \\
\text { strength development corresponding } \\
\text { to LFC-CTW0 (\%) }\end{array}$ \\
\hline 7 & & 100 \\
& LFC-CTWO & 81 \\
28 & LFC-CTW25 & 89 \\
& LFC-CTW50 & 100 \\
56 & LFC-CTWO & 113 \\
& LFC-CTW25 & 80 \\
& LFC-CTW50 & 100 \\
& LFC-CTWO & 105 \\
& LFC-CTW25 & 63
\end{tabular}

development of LFC-CTW25 performed as well as LFC-CTW0 with a peak point achievement at 56 curing days, which was valued at $0.61 \mathrm{MPa}$. The highest split tensile bearing capacity was achieved by LFC-CTW25. On the other hand, Adekunle et al. (2017) in their study found that an increase in ceramic tile aggregate replacement proportion in normal concrete causes a decrease in the splitting tensile strength value. As this study was using ceramic dust as partial cement replacement material in lightweight foamed concrete which contains very fine sand and foam bubbles only, the embedded clayey characteristic in ceramic tile wastes (Bhavana and Rambabu, 2017) in the mix might play a more important role in improving the bonding between the cement paste and the fine particles in the foamed concrete at the optimal replacement level, i.e., $25 \%$ ceramic tile powder. Thus, a better interlocking force is created to resist the tensile strength upon splitting of the LFC-CTW25. Another study done by Medina et al. (2012)showed that when the ceramic coarse aggregate replacement level was up to $25 \%$, there is an increment of splitting tensile strength. It was increased up to $12-25 \%$ if compared to the splitting tensile strength of the control mix.

Meanwhile, Table 6 shows that foamed concrete incorporated with $25 \%$ ceramic tile wastes increases its strength steadily and supersedes that of the control mix at the ages of 28 and 56 days. Therefore, it can be concluded that the replacement of ceramic tile wastes at $25 \%$ in cement improves the splitting tensile strength of LFC. Table 7 shows the standard deviation for the splitting tensile strength PI of each mixture. The standard deviation is in the range of $0.009-0.247 \mathrm{MPa}$ per $1,000 \mathrm{~kg} / \mathrm{m}^{3}$, which indicates that the splitting tensile strength tends to be close to the mean of the set data in each mixture.

\section{Modulus Elasticity Analysis}

Elastic deformation of LFC-CTW0, LFC-CTW25, and LFCCTW50 was measured in terms of longitudinal deformation during stress application onto the specimens. The calculated day-56 modulus of elasticity test values for LFC-CTW0, LFCCTW25, and LFC-CTW50 are tabulated in Table 8.

Table 6 shows that elastic modulus for LFC at the curing age of 56 days, showing a minor decline with the incorporation of ceramic tile wastes. The highest elastic modulus is achieved by LFC-CTW0, which is valued at $0.69 \mathrm{GPa}$, yet the lowest elastic modulus is achieved by LFC-CTW25, which is valued at $0.54 \mathrm{GPa}$. Studies of clay tile chip replacement with coarse aggregate in concrete by Mohan et al. (2018) showed similar outcomes, where the elastic modulus decreases with higher replacement proportion of coarse aggregate and around 10\% of reduction on elastic modulus is obtained for the specimen with $25 \%$ ceramic tile aggregate replacement. In general, a high volume of ceramic tile waste powder as partial cement replacement material reduces the modulus elasticity due to the lower stress-strain value in the elastic region. 
TABLE 7 | Standard deviation of the splitting tensile strength performance index for each mixture.

\begin{tabular}{llc} 
Concrete age (days) & Specimen name & Standard deviation based on the splitting tensile strength performance index $\left(\mathbf{M P a} / \mathbf{1}, \mathbf{0 0 0} \mathbf{~ k g} / \mathbf{m}^{\mathbf{3}}\right.$ ) \\
\hline 7 & LFC-CTW0 & 0.052 \\
& LFC-CTW25 & 0.033 \\
LFC-CTW50 & 0.247 \\
28 & LFC-CTWO & 0.048 \\
& LFC-CTW25 & 0.031 \\
56 & LFC-CTW50 & 0.072 \\
& LFC-CTW0 & 0.009 \\
& LFC-CTW25 & 0.048 \\
& LFC-CTW50 & 0.018
\end{tabular}

\begin{tabular}{|c|c|c|c|c|c|}
\hline Specimen name & $\mathrm{F}^{\mathrm{a}}(\mathrm{MPa})$ & $\mathrm{S}_{2}{ }^{\mathrm{b}}(\mathrm{MPa})$ & $\mathrm{S}_{1}^{\mathrm{c}}(\mathrm{MPa})$ & $\varepsilon_{2}^{d}(\mathrm{~mm} / \mathrm{mm})$ & $E^{e}(G P a)$ \\
\hline LFC-CTWO-56DAYS & 4.71 & 1.88 & 0.021092 & 0.002763 & 0.69 \\
\hline LFC-CTW50-56DAYS & 2.90 & 1.16 & 0.027493 & 0.001811 & 0.64 \\
\hline
\end{tabular}

a Maximum compressive strength, MPa.

${ }^{b}$ Stress of the specimen corresponding to $40 \%$ of maximum load applied, MPa.

${ }^{c}$ Stress of the specimen corresponding to a longitudinal strain of 50 millionths, MPa.

${ }^{d}$ Longitudinal strain of the specimen from stress, $\mathrm{mm} / \mathrm{mm}$.

${ }^{e}$ Modulus of elasticity, GPa, $E=\left(S_{2}-S_{1}\right) /\left(\varepsilon_{2}-0.00005\right)$.

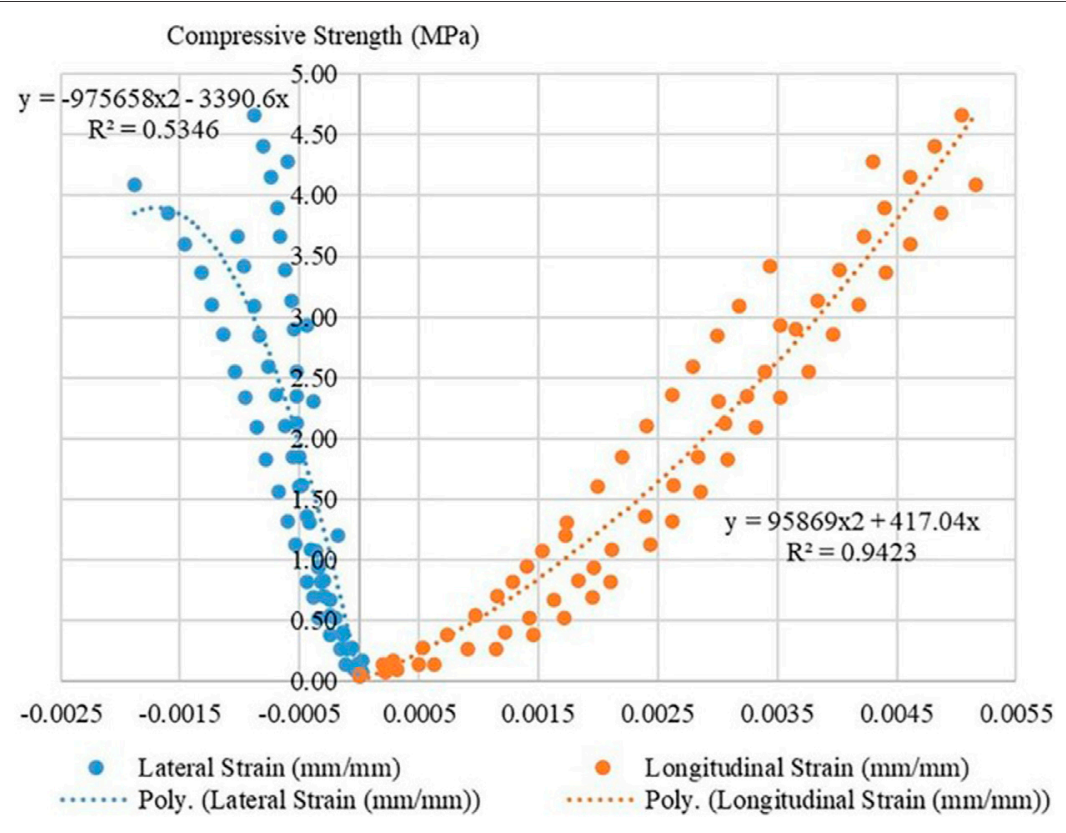

FIGURE 8 | Compressive toughness of LFC-CTWO at 56 days' curing age.

\section{Compressive Toughness Analysis}

The compressive toughness of LFCs in this study was computed based on the total energy that can be absorbed by the LFCs before they failed in compression. Stress-strain curves of LFC-CTW0, LFC-CTW25, and LFC-CTW50 for 56 days were plotted and stopped at the compression breaking point to find out the trend line equation as shown in Figures 8-10, respectively. The compressive toughness results for LFC-CTW0, LFC-CTW25, and LFC-CTW50 are tabulated in Table 9.

Figures 8-10 show the same trend with compressive strength development where the curve trends indicate that the compressive strength increases with increased corresponding strains at a decreasing rate. The $R^{2}$ values indicate that the trend is well fitted with the mathematical equations. The optimum 

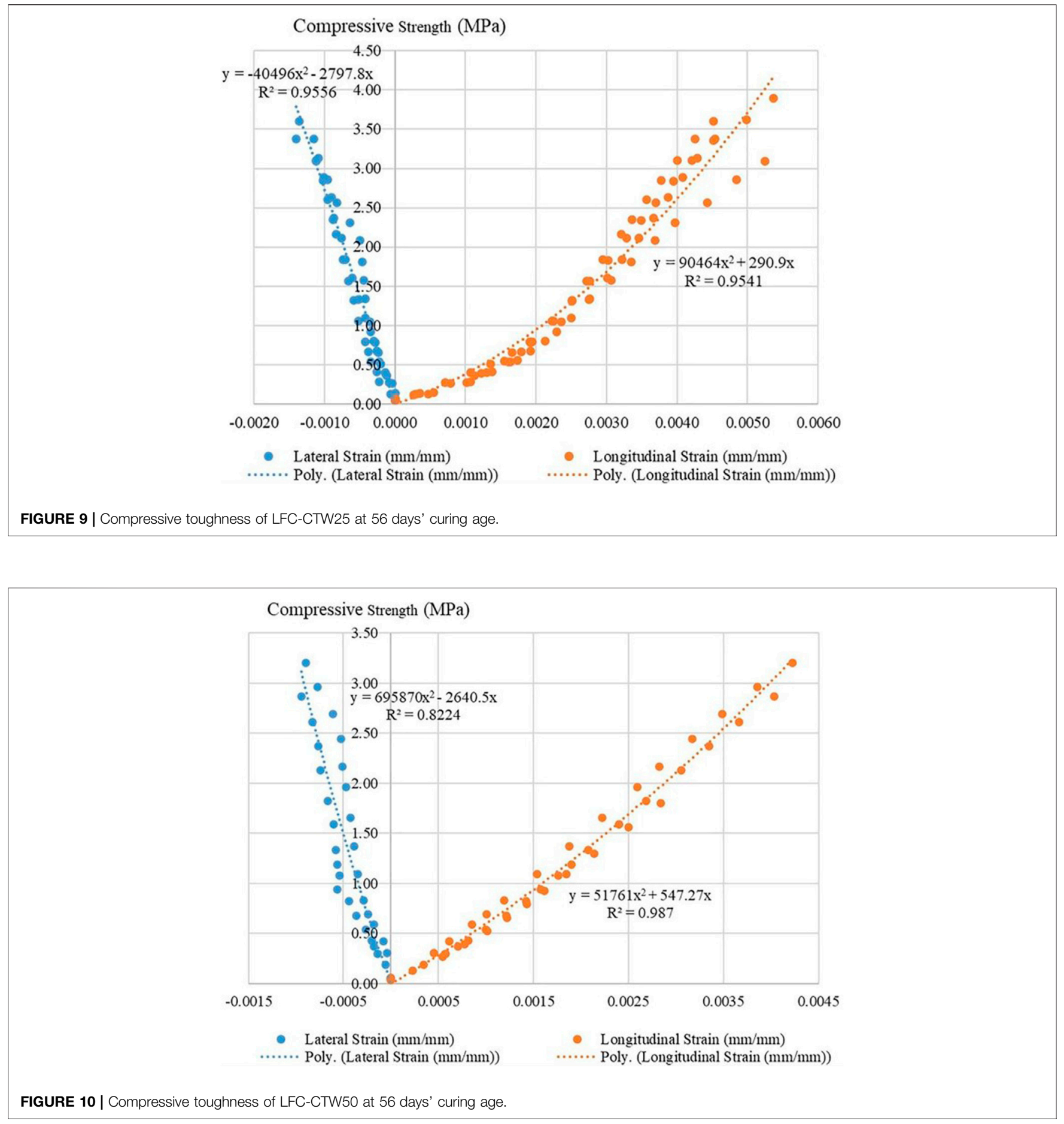

TABLE 9 | Compressive toughness of LFC-CTWO, LFC-CTW25 and LFC-CTW50 at age of 56 days.

\section{Specimen name}

LFC-CTWO-56DAYS

LFC-CTW25-56DAYS

LFC-CTW50-56DAYS

\section{F (MPa)}

4.71

3.56

2.90 $\varepsilon f^{\mathrm{a}}\left(10^{-6} \mathrm{~mm} / \mathrm{mm}\right)$

5,164

4,868

3,880
Curves' trend line equation

$$
\begin{gathered}
\sigma=95,869 \varepsilon^{2}+417.04 \varepsilon \\
\sigma=90,464 \varepsilon^{2}+290.9 \varepsilon
\end{gathered}
$$$$
\sigma=51,761 \varepsilon^{2}+547.27 \varepsilon
$$

$\boldsymbol{R}^{2}$

0.9423

0.9541

0.9870 $\mu_{t}^{b}\left(10^{+15} \mathrm{~J} / \mathrm{m}^{3}\right)$

4.40

3.48

1.01



${ }^{b}$ Compressive toughness, $\left(10^{+15} \mathrm{~J} / \mathrm{m}^{3}\right)$. 



FIGURE 11 | Microstructure of lightweight foamed concrete with and without $50 \%$ ceramic tile waste powder. (A) LFC with $50 \%$ ceramic tile waste powder. (B) Control LFC (without ceramic tile waste powder).

compressive toughness achieved by LFC-CTW0, LFC-CTW25, and LFC-CTW50 at day 56 is valued at $4.40 \times 10^{15}, 3.48 \times 10^{15}$, and $1.01 \times 10^{15} \mathrm{~J} / \mathrm{m}^{3}$, respectively, as tabulated in Table 9. Overall, the compressive toughness of LFC-CTW25 behaves most closely to the results of the control set at day 56 concrete age. Therefore, it can be concluded that foamed concrete with $25 \%$ ceramic tile wastes as partial cement replacement materials is a better substitute percentage for maintaining the compressive toughness of the lightweight foamed concrete.

Lightweight foamed concrete prepared with ceramic dust microstructure at $\times 200$ image is observed and print screened. The SEM analyses for both cement and ceramic dust are shown in Figure 11 to justify the pozzolanic activity and micro-packing effect of ceramic tile powder in LFCs for mechanical strength development and more uniform air void distribution. Besides, the BET surface analysis has helped to justify the micro filler effect, as well as sieve analysis in Figure 2, showing the clayey behavior of ceramic tile waste powder in LFC, especially in enhancing the tensile capacity of LFCs. Similarly, Lim et al. (2017) found that a high volume of refined quarry dust with larger surface area than fine sand in LFC resulted to smaller voids and that the artificial air voids did not coalesce in larger pores and remained in smaller discrete voids upon hardening.

\section{CONCLUSION}

Some conclusions can be drawn based on the following study:

1. The optimal water-to-cement ratio is achievable at the range of 0.60-0.64 for lightweight foamed concrete with a density of $1,200 \mathrm{~kg} / \mathrm{m}^{3}$.

2. The incorporation of ceramic tile waste powder into foamed concrete decreases the workability when the cement replacement proportion increases due to the larger BET surface area of the ceramic tile waste powder.

3. The incorporation of ceramic tile waste powder in foamed concrete increases the foam percentage to achieve the desired density at equivalent water-to-cement ratios. This is because the larger BET surface area of ceramic tile waste powder requires more quantity of water and foam.
4. The incorporation into foamed concrete of $25-50 \%$ ceramic tile wastes as partial cement replacement material led to a reduction in the value of compressive strength, modulus elasticity, and compressive toughness. The results might be due to the replacement of cement in the large portion by the content of the ceramic tile waste powder, and dilution was the dominant effect of the pozzolanic reaction between calcium hydroxide and reactive silica in ceramic tile waste powder.

5. The incorporation into foamed concrete of $25 \%$ ceramic tile wastes as partial cement replacement material led to a slight increase in the value of splitting tensile capacity. This might be due to the clayey and cohesive behaviors of the ceramic tile waste powder enhancing the bonding between cement paste and the fine particles.

6. The outcome from this study showed that the optimal partial replacement of ceramic tile waste powder of $25 \%$ with cement into lightweight foamed concrete might improve the splitting tensile strength but not the compressive strength. This is as an important parameter for the lightweight foamed concrete to improve its resistance to direct tensile strength.

\section{DATA AVAILABILITY STATEMENT}

The original contributions presented in the study are included in the article/supplementary material, further inquiries can be directed to the corresponding authors.

\section{AUTHOR CONTRIBUTIONS}

All authors listed have made a substantial, direct, and intellectual contribution to the work and approved it for publication.

\section{FUNDING}

The support provided by the Universiti Tunku Abdul Rahman (UTAR), Grant No. 6200/LG3, and Active Pozzolan Technology Sdn. Bhd. for this study is very much appreciated. 


\section{REFERENCES}

Adekunle, A. A., Abimbola, K. R., and Familusi, A. O. (2017). Utilization of Construction Waste Tiles as a Replacement for Fine Aggregates in Concrete. Eng. Technol. Appl. Sci. Res. 7 (5), 1930-1933. doi:10.48084/etasr.1071

Amran, Y. H. M., Farzadnia, N., and Abang Ali, A. A. (2015). Properties and Applications of Foamed concrete; a Review. Construction Building Mater. 101 (1), 990-1005. doi:10.1016/j.conbuildmat.2015.10.112

ASTM (2006a). ASTM C136 - 06: Standard Test Method of Sieve Analysis of Fine and Coarse Aggregates. West Conshohocken: ASTM International.

ASTM (2007b). ASTM C1437 - 07: Standard Test Method for Flow of Hydraulic Cement Mortar. West Conshohocken: ASTM International.

ASTM (2005a). ASTM C150 - 05: Standard Specification for Portland Cement. West Conshohocken: ASTM International.

ASTM (2006c). ASTM C1602 - 06: Standard Specification for Mixing Water Used in the Production of Hydraulic Cement Concrete. West Conshohocken: ASTM International.

ASTM (2005b). ASTM C1611 - 05: Standard Test Method for Slump Flow of SelfConsolidating Concrete. West Conshohocken: ASTM International.

ASTM (2007a). ASTM C192 - 07: Standard Practise for Making and Curing Concrete Test Specimen in the Laboratory. West Conshohocken: ASTM International.

ASTM (2014). ASTM C230 - 14: Standard Test for Flow Table Use in Tests of Hydraulic Cement. West Conshohocken: ASTM International.

ASTM (2016). ASTM C260 - 10a: Standard Specification for Air-Entraining Admixtures for Concrete. West Conshohocken: ASTM International.

ASTM (2002). ASTM C469 - 02: Standard Test Method for Static Modulus of Elasticity and Poisson's Ratio of Concrete in Compression. West Conshohocken: ASTM International.

ASTM (2004). ASTM C496 - 04: Standard Test Method for Splitting Tensile Strength of Cylindrical Concrete Specimens. West Conshohocken: ASTM International.

ASTM (2006b). ASTM C778 - 06: Standard Specification for Standard Sand. West Conshohocken: ASTM International.

ASTM (2012). ASTM C796 - 12: Standard Test Method for Use in Producing Cellular Concrete Using Preformed Foam. West Conshohocken: ASTM International.

Aswin, S., Mohanalakshmi, V., and Rajesh, A. A. (2018). Effects of Ceramic Tile Powder on Properties of Concrete and Paver Block. Glob. Res. Dev. J. Eng. 3 (4), 84-87.

Bhavana, N., and Rambabu, C. H. (2017). Study of Mechanical Properties of Lightweight Aggregate concrete by Using Pumice Stone, Ceramic Tiles and CL Lightweight Bricks. Int. Res. J. Eng. Tech. 4 (06), 3071-3079.

Bhogilal, V. R., and Jayantilal, M. T. (2018). Pertinence of Ceramic Waste in Self Compacted Concrete as Partial Equivalent of Cement. Int. Res. J. Eng. Tech. 5 (11), 344-349.

Brady, K. C., Watts, G. R. A., and Jones, M. R. (2001). Specification for Foamed Concrete. Wokingham: TRL Limited.

BSI (2000b). BS EN 12390 - Part 6: Testing Hardened Concrete - Part 6: Tensile Splitting Strength of Test Specimens. London: British Standards Institution.

BSI (2002). BS EN 12390- Part 3: Testing Hardened ConcreteCompressive Strength of Test Specimens. London: British Standards Institution.

Crow, J. M. (2008). The concrete Conundrum Chemistry World February. Cambridge: Royal Society of Chemistry. Available at: : https://www. chemistryworld.com/features/the-concrete-conundrum/3004823.article (Accessed July 1, 2021).

Daniyal, M., and Ahmad, S. (2015). Application of Waste Ceramic Tile Aggregates in concrete. Int. J. Innovative Res. Sci. Eng. Tech. 4 (12), 12808-12815. doi:10. 15680/IJIRSET.2015.0412128

El-Dieb, A. S., Taha, M. R., Kanaan, D., and Aly, S. T. (2018). Ceramic Waste Powder: From Landfill to Sustainable Concretes. Proc. Inst. Civil Eng. Construction Mater. 171, 109-116. doi:10.1680/jcoma.17.00019

Global Bio Synergy Sdn (2016). : Global Bio Synergy Sdn Bhd. N.D. MIS-OTH 160394. Global Bio Synergy Sdn. Bhd.: Kuala Lumpur.

Heidari, A., and Tavakoli, D. (2013). A Study of the Mechanical Properties of Ground Ceramic Powder concrete Incorporating Nano-SiO2 Particles.
Construction Building Mater. 38, 255-264. doi:10.1016/j.conbuildmat.2012. 07.110

Jacob, A. E., Aggarwal, A., and Kushwaha, Y. K. (2017). Utilisation of Ceramic Waste as a Replacement of Aggregates and its Effect on Variation of Expenditure. Int. J. Innovative Res. 5 (3), 262-268.

Javier, G. F., Francisca, Q. V. M., Carlos, G. A., David, C. V., Victoria, Z., and Carmen, S. M. M. (2016). Life Ceram - Zero Waste in Ceramic Tile Manufacture. Key Eng. Mater. 663, 23-33. doi:10.4028/www.scientific.net/ KEM.663.23

Lee, Y. L., Lim, S. K., Lim, S. K., Lim, M. H., Lee, F. W., and Yew, M. K. Y. (2021). Effect of Ceramic Dust as Partial Replacement of Cement on Lightweight Foamed concrete. Ijie 13 (4), 304-312. doi:10.30880/ijie. 2021.13.04.029

Lim, S. K., Tan, C. S., Li, B., Ling, T.-C., Hossain, M. U., and Poon, C. S. (2017). Utilizing High Volumes Quarry Wastes in the Production of Lightweight Foamed concrete. Construction Building Mater. 151, 441-448. doi:10.1016/j. conbuildmat.2017.06.091

Lim, S. K., Tan, C. S., Lim, O. Y., and Lee, Y. L. (2013). Fresh and Hardened Properties of Lightweight Foamed concrete with palm Oil Fuel Ash as Filler. Construction Building Mater. 46, 39-47. doi:10.1016/j.conbuildmat.2013. 04.015

Medina, C., Sánchez de Rojas, M. I., and Frías, M. (2012). Reuse of Sanitary Ceramic Wastes as Coarse Aggregate in Eco-Efficient Concretes. Cement and Concrete Composites 34, 48-54. doi:10.1016/j.cemconcomp.2011. 08.015

Mohan, A., Thomas, J., and Joseph, N. (2018). Use of clay Tile Chips as Coarse Aggregate in concrete. IOP Conf. Ser. Mater. Sci. Eng. 396, 012002. doi:10.1088/ $1757-899 X / 396 / 1 / 012002$

Sallal, A. K. (2018). Use Foam concrete in Construction Works. Int. J. Res. Adv. Eng. Tech. 4 (2), 15-20.

Samadi, M., Warid Hussin, M., Mohd Sam, A. R., and Lim, H. S. (2015). Effect of Ceramic Powder on Mortar Concrete. Amr 1113, 62-67. doi:10.4028/www. scientific.net/amr.1113.62

Shah, Z. (2015). "Analysis of Construction and Demolition Waste for Infrastructure Projects," Independent Study. Available at: https://www. researchgate.net/publication/281062658_Analysis_of_Construction_and_ Demolition_Waste_for_Infrastructure_Projects (Accessed July 1, 2021).

Sika (2017). Sika-AER Air Entraining Product Data Sheet. Bogor : Sika Indonesia.

Standards Malaysia (2014). MS EN 197-1: Cement - Part 1: Composite, Specifications and Conformity Criteria for Common Cements (First Revision). Malaysia: Department of Standards Malaysia.

Tiong, H. Y., Lim, S. K., Lee, Y. L., Ong, C. F., and Yew, M. K. (2020). Environmental Impact and Quality Assessment of Using Eggshell Powder Incorporated in Lightweight Foamed concrete. Construction Building Mater. 244, 118341. doi:10.1016/j.conbuildmat.2020.118341

Zhao, X., Lim, S.-K., Tan, C.-S., Li, B., Ling, T.-C., Huang, R., et al. (2015). Properties of Foamed Mortar Prepared with Granulated Blast-Furnace Slag. Materials 8 (2), 462-473. doi:10.3390/ma8020462

Conflict of Interest: The authors declare that the research was conducted in the absence of any commercial or financial relationships that could be construed as a potential conflict of interest.

Publisher's Note: All claims expressed in this article are solely those of the authors and do not necessarily represent those of their affiliated organizations, or those of the publisher, the editors and the reviewers. Any product that may be evaluated in this article, or claim that may be made by its manufacturer, is not guaranteed or endorsed by the publisher.

Copyright (C) $2022 \mathrm{Lim}$, Lee, Yew, Ng, Lee, Kwong and Lim. This is an open-access article distributed under the terms of the Creative Commons Attribution License (CC $B Y)$. The use, distribution or reproduction in other forums is permitted, provided the original author(s) and the copyright owner(s) are credited and that the original publication in this journal is cited, in accordance with accepted academic practice. No use, distribution or reproduction is permitted which does not comply with these terms. 